SPECIAL CONTRIBUTION

\title{
Progress of Management and Outcome of Limited Stage Small Cell Lung Cancer in the Past Decade
}

\author{
Ritsuko U. Komaki ${ }^{1}$
}

(JJLC. 2010;50:265-271)

KEY WORDS — Small cell lung cancer, Radiation therapy, Prophylactic cranial irradiation (PCI)

In the USA, an estimated 219,440 patients will be diagnosed with lung cancer in 2009. Small cell lung cancer comprises approximately $16-20 \%$ of all lung cancer. One fifth of them will have limited stage small cell lung cancer. The integration of thoracic radiotherapy (TRT) with systemic chemotherapy for the treatment of limitedstage small cell lung cancer (LSCLC) has been widely studied. Two meta-analyses, published in the early 1990s, confirmed that adding TRT to chemotherapy significantly improved long-term survival for patients with LSCLC. A recent overview of prospective research in LSCLC, included 26 randomized clinical trials initiated by cooperative groups in North America between 1972 and 1992, and only 5 studies showed statistically significant survival prolongation in the experimental arm compared with the control arm. All five positive trials studied some aspect of TRT. Traditionally, modest total doses of radiation, ranging from 45-50 Gy, were employed because of the observed responsiveness of small-cell lung cancer to radiotherapy. Although high clinical response rates are expected with combined modality therapy, durable local tumor control is poor when modest-dose, conventionally fractionated TRT is employed. Intensifying the radiotherapy course by accelerating the time to complete treatment (while maintaining the same nominal total radiation dose) appears to be an effective strategy in LSCLC. Intergroup trial 0096 (INT 0096) randomized patients to either conventional (180 cagy $Q D \times 25$ fractions [45 Gy in 5 weeks]) or hyperfractionated, accelerated (150 cagy BID $\times 30$ fractions [45 Gy in 3 weeks]) TRT. TRT was initiated with the first cycle of etoposide/cisplatin (PE) chemotherapy. Mature results of this trial demonstrate statistically significant improvement in overall survival for the accelerated TRT. Fiveyear survival was $26 \%$ with accelerated RT compared with $16 \%$ for patients receiving conventional TRT. Patterns of recurrence reflected improved local and local plus distant recurrence rates with accelerated TRT, suggesting that local treatment has a significant impact on ultimate outcome in LSCLC. The cumulative rate of local tumor relapse was $75 \%$ with once-daily TRT compared with $42 \%$ with twice-daily TRT. The major increased toxicity of the accelerated regimen was a doubling of the severe (e.g. grade $3+4$ ) acute esophagitis rate from $11 \%$ by daily RT to $27 \%$, although TRT was not done by conformal radiotherapy. To improve local control better than $42 \%$ without increasing rate of esophagitis, Radiation Therapy Oncology Group (RTOG) has studied a concomitant boost (CB) strategy in LSCLC. This approach allows acceleration of TRT but only requires hyperfractionated TRT during part of the treatment course. Moreover, BID large field TRT can be avoided. A phase I trial has been completed assessing the MTD for concomitant boost TRT in LSCLC (R 9712). TRT was initiated with the first of 4 cycles of PE chemotherapy. Accelerated TRT, $61.2 \mathrm{~Gy}$ in 34 fractions of 1.8 $\mathrm{Gy} / \mathrm{Fx}$ in 5 weeks, with BID TRT during the final 9 treatment days, was determined to be the maximum tolerated dose (MTD). A subsequent phase II study, RTOG 0239, employed the 61.2 Gy concomitant boost regimen with concurrent chemotherapy for LSCLC resulted in $17 \%$ acute Gr. 3 + esophagitis compared to $27 \%$ with
1Department of Radiation Oncology, University of Texas, M.D. Anderson Cancer Center, Houston.

Reprints: Ritsuko U. Komaki, Department of Radiation Oncol- ogy, University of Texas, M.D. Anderson Cancer Center, Unit 97, 1515 Holcombe Blvd.-Unit 097, Houston, TX 77030, USA.

※第 50 回日本肺癌学会総会招請講演 2 . 
BID TRT with 45 Gy in 3 weeks by INT 0096. The Patterns of Care Study published in 2003 noted that fewer than $10 \%$ of patients with LSCLC received this regimen hyperfractionated, accelerated (150 cagy BID $\times 30$ fractions [45 Gy in 3 weeks]) TRT, while more than $80 \%$ were treated with QD TRT. The Cancer and Leukemia Group B (CALGB) have studied high-dose QD TRT. CALGB 8837, a phase I study, was designed to determine the maximum-tolerated dose (MTD) of TRT in both standard QD and accelerated BID schedules. The efficacy of radiotherapy can be predicted by calculating the biologic effective dose (BED). The BED reflects the tumor type (doubling time), dose per fraction, nominal total dose and may also take into account the time to complete therapy. In comparison to the accelerated 45 Gy BID regimen studied in INT 0096, both the CALGB TRT regimen of $70 \mathrm{~Gy} \mathrm{QD}$ and the RTOG concomitant boost approach yield substantially higher Beds. For example, assuming a potential tumor doubling time of 5 days, the predicted increase in $\mathrm{BED}$ would range from 1.3 to 1.6 (e.g. $30 \%$ to $60 \%$ increase in efficacy) for the CALGB and RTOG experimental regimens compared with 45 Gy BID.

\section{PREDICTED BIOLOGIC EFFECTIVE DOSE (BED) OF THORACIC RADIOTHERAPY REGIMENS}

In summary, defining an optimal TRT regimen in LSCLC remains critical and will have a major impact on clinical practice. Intergroup study 0096 clearly established that improving the efficacy of thoracic radiotherapy could significantly impact survival in patients with LSCLC, although local control and toxicity will need improvement. Superior outcomes on an experimental arm would lead to establishing a change in the standard of care for patients with LSCLC. Conversely, if the best outcomes were observed with accelerated 45 Gy BID TRT, then the results of this study would provide convincing and definitive evidence for practitioners to adopt this regimen. RTOG 0239 was a phase II study based on the arm 4 of RTOG 97-12 showed excellent local control and lower rates of severe acute esophagitis (ASCO 2009).

Brain metastases are an exceedingly common cause of morbidity and mortality in cancer patients. Without intervention up to $50 \%$ of patients with small cell carcinoma of the lung will fail in the CNS. Prophylactic cranial irradiation has been shown to decrease the inci- dence of brain metastasis and provide an overall survival benefit to patients with limited stage SCLC in complete remission. Despite a survival benefit, some practitioners have hesitated to utilize PCI citing fears of CNS dysfunction secondary to radiation effects.

Previous trials addressing neurocognitive function in patients with SCLC treated with PCI have largely been retrospective and failed to include baseline measures of cognitive function. Large prospective trials have addressed cognitive changes but have been criticized for their testing methods. Traditional indices such as the Karnofsky performance status (KPS) are measures of physical ability and do not address brain function. The mini-mental status examination (MMSE), employed in previous trials, is not a sensitive measure of cognition. MMSE detects only profound dysfunction and fails to measure subtle alterations in learning and memory, executive functioning etc. In contrast, standardized measures of brain function which are easily performed are both specific and sensitive. These measures of NCFT now being used both to stratify patients enrolled in randomized trials and as primary endpoints.

We have studied prospectively for limited small cell lung cancer patients who have been assessed by adequate neurocognitive function before PCI. Amazingly our study has shown $83 \%$ of them had already neurocognitive dysfunction before treatment without obvious brain metastasis which was most likely related with paraneoplastic syndrome or micro metastasis in the brain.

We have updated the results of a prospective study formally assessing neuropsychological function in patients with small cell carcinoma of the lung treated with prophylactic cranial irradiation. All patients enrolled were tested prior to cranial irradiation. When possible, patients underwent repeat testing following PCI at early and late intervals.

In 2008, the PCI99 Inter group presented results of a randomized phase III study 720 LS SCLC patients with a complete response to first-line therapy, randomized to receive 25 or 36 Gy PCI. Toxicities and treatment delivery were not different between two arms Patients who received 36 Gy had a nonsignificant decrease in brain metastases and, for unclear reasons, a worse overall survival $(\mathrm{P}=.03)$. Thus, $\mathrm{PCI}$ at $25 \mathrm{~Gy}$ is recommended for $\mathrm{LS}$ and ES SCLC patients who respond to first-line therapy.

In summary, we have made progress of the manage- 
ment and outcome for limited stage small cell lung cancer by concurrent cisplatin based chemotherapy and TRT followed by PCI for CR patients. Now we need to improve better local control with higher dose of TRT and more effective systemic agents without increasing normal tissue toxicity. 
和訳 :

野中哲生 1 ・中山優子 1 ・早川和重 2,3

索引用語 一一小細胞肺癌, 放射線治療, 予防的全脳照射

\section{はじめに}

米国の 2009 年肺がん新患数は推定 179,000 人である. 小細胞肺癌は全肺癌の 20 2 $25 \%$ を占め, そのうち約 $20 \%$ が限局型小細胞肺癌（LSCLC：Limited-stage small cell lung cancer）といわれている（図1).

\section{限局型小細胞肺癌における胸部への放射線治療}

LSCLCに対する治療では 1990 年代に報告された Meta-analysis の結果から, 化学療法単独だけではなく胸 部一の放射線治療（TRT：Thoracic radiotherapy）の併 用が標準的な治療として位置付けられ，その併用時期に ついては可能な限り早期に併用することが重要であると された. 1,2 TRT の線量は通常分割で 45〜50 Gy とする ことが一般的であり，一次効果は良好であったが，十分 な局所制御期間は得られなかった. Turrisi らは LSCLC 症例に対し化学療法はシスプラチン $(\mathrm{CDDP})+$ エトポシ ド（VP-16）を用い，照射方法別に通常分割群（QD 群 : 1 回 $1.8 \mathrm{~Gy}, 1$ 日 1 回, 総線量 $45 \mathrm{~Gy} / 5$ 週間), 加速多分割 群(BID 群: 1 回 $1.5 \mathrm{Gy,} 1$ 日 2 回, 総線量 $45 \mathrm{~Gy} / 3$ 週間) に症例を割り付ける無作為比較試験を行った（INT 0096, 図 2). 3 治療成績は $\mathrm{QD}$ 群の 5 年生存率が $16 \%$, 局

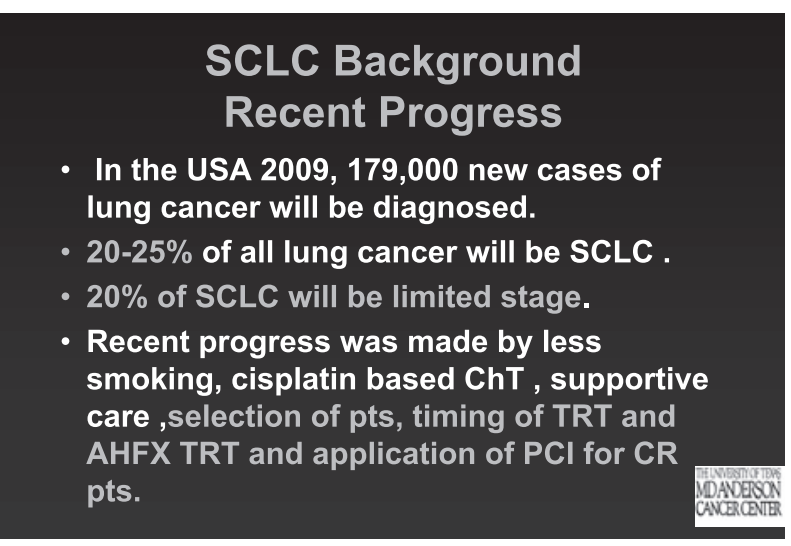

図 1.
所再発率が $75 \%$ であったのに対し, BID 群では 5 年生 存率 $26 \%$, 局所再発率 $42 \%$ と有意に良好な結果が得ら れた．また，BID 群で局所再発だけではなく遠隔転移の 発生が有意に低率であったため, LSCLC の治療では局所 に強力な治療を施行することによって良好な局所制御率 を導くことが可能となり, さらに生存率の向上が期待で きることが示唆された (図 3 )。この研究では 3 次元的な 放射線治療が施行されていなかったこともあり, BID 群で重篤な食道炎が $27 \%$ と, $\mathrm{QD}$ 群の $11 \%$ に比較して 有意に高率で認められたことが問題となった.

RTOG（Radiation Therapy Oncology Group）は INT 0096 に扔ける BID 群の治療効果を担保し, さらに急性 期に認められた有害事象を抑えることに注目し，TRT の至適線量・照射方法を検討するための第 I 相試験 （RTOG 9712）を行った. ${ }^{4}$ このトライアルでは化学療法 は CDDP + VP-16 を 4 コース，照射法には Concomitant boost（CB）法を用いた. TRTの Maximum tolerated dose (MTD) は $61.2 \mathrm{~Gy}$ (1 コース目の化学療法に同時併 用, 1 回 $1.8 \mathrm{~Gy}, 34$ 分割 $/ 5$ 週間, 最後の 9 回のみ 1 日 2 回 $(\mathrm{CB}))$ であった。この結果が引き続き行われた第 II 相試験（RTOG 0239）で用いられた（図 4, 5). ${ }^{5}$ RTOG 0239 では重篤な食道炎の発生は $18 \%$ であり INT 0096

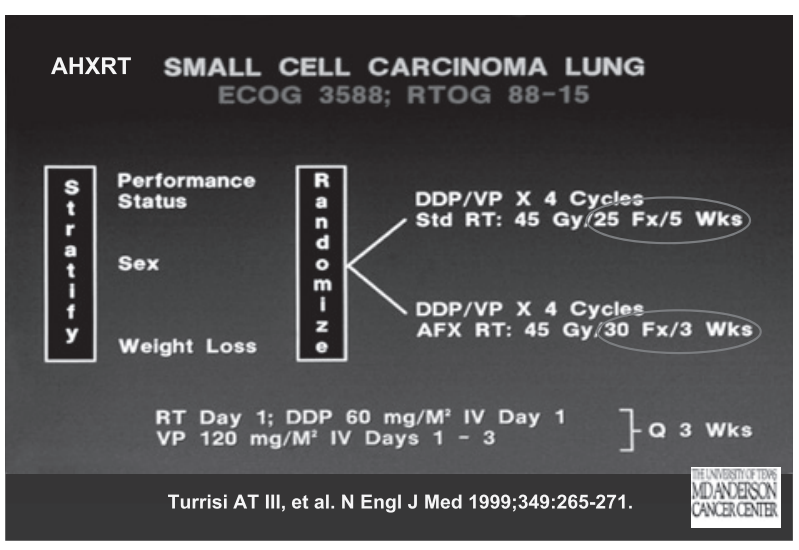

図 2.
1神奈川県立がんセンター放射線腫瘍科；2第 50 回肺癌学会総会 会長 ; 3 北里大学医学部放射線科学.

責任著者：野中哲生，神奈川県立がんセンター放射線腫瘍科，

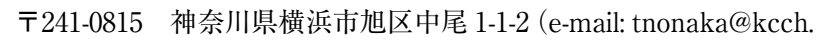
jp). 


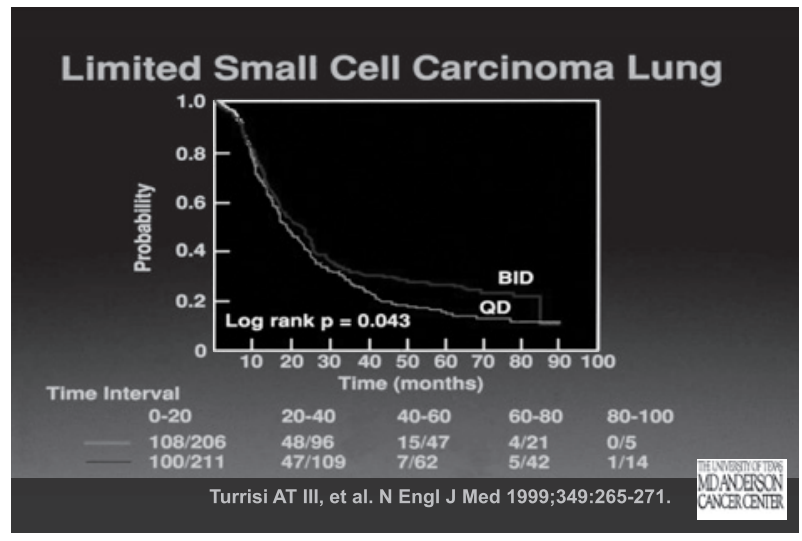

図3.

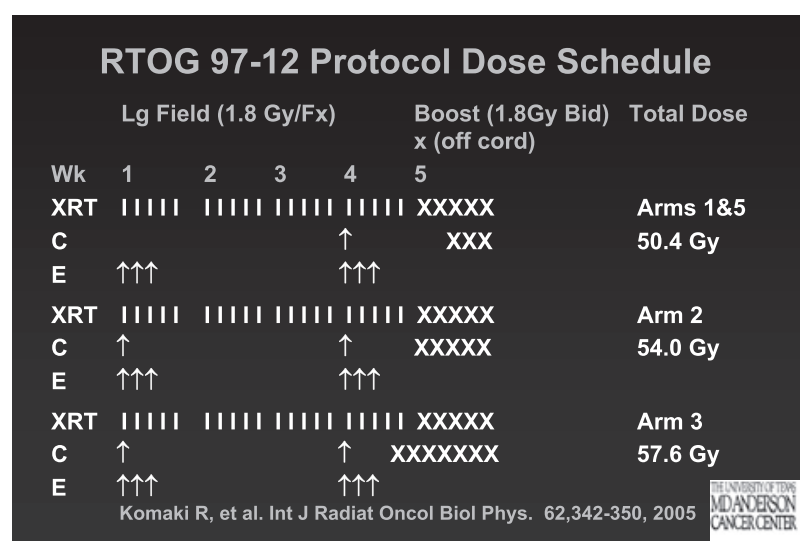

図 4.

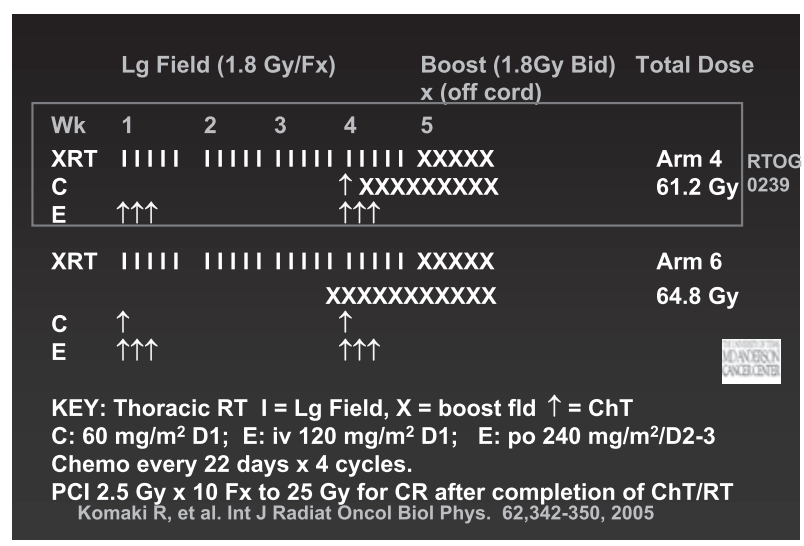

図 5.

に扔ける BID 群の $27 \%$ を下回る結果が得られ（図 6), 治療成績は奏功率 $90 \%, 2$ 年生存率 $37 \%$ と良好であった (図 7, エンドポイントが INT 0096 と異なるためか単純 な比較はされなかった). TRTに CB 法を導入すること によって，広い照射野での多分割照射が避けられるため

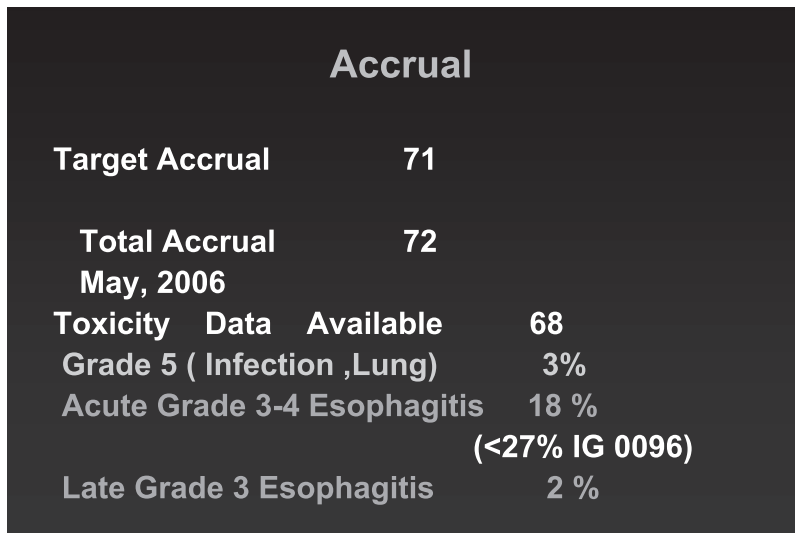

図 6.

\section{Results}

- 72 patients(71 eligible): $6 / 20 / 2003$ to $5 / 23 / 2006$

- The median follow-up time:

$>$ All patients: 19.0 months

$>$ Alive patients: $\mathbf{3 0 . 4}$ months

- The 2-year survival rate: $37 \%$ [95\% Cl: 25.6- 47.7]

- Response rates at 2 months post RX:

RR (90\%), CR: $41 \%$, PR: $39 \%$, SD: $10 \%$ and PD: $6 \%$

Died prior to 2 months post-treatment: $3 / 71$ (4\%)

- Disease-free survival (2-year): $20 \%$

RT compliance: $95 \%$

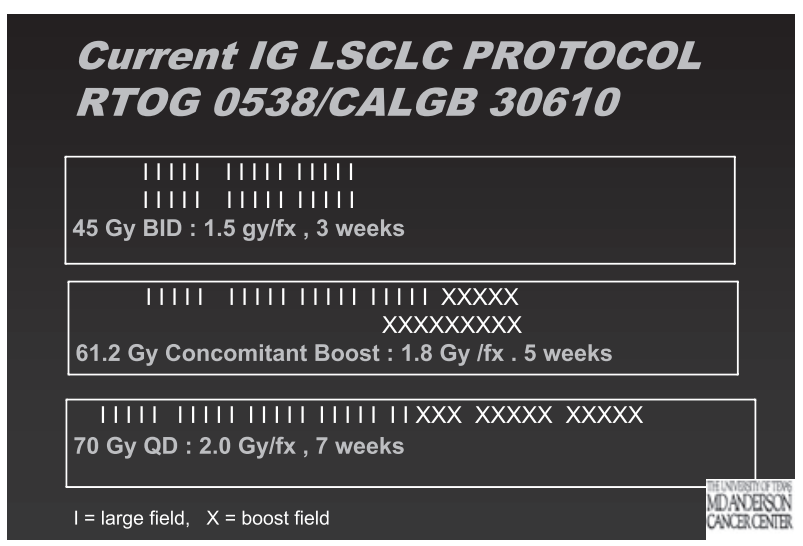

図 8.

重篤な有害事象の発症を低減し，かつ病変に対しては強 度の高い治療を施行することが可能となった。一方, CALGB（The Cancer and Leukemia Group B）では BID および $\mathrm{QD}$ の至適線量を第 $\mathrm{I}$ 相試験で検討した結果, MTD がそれぞれ $45 \mathrm{~Gy} / 30$ 分割/3 週間以上, $70 \mathrm{~Gy} / 35$ 


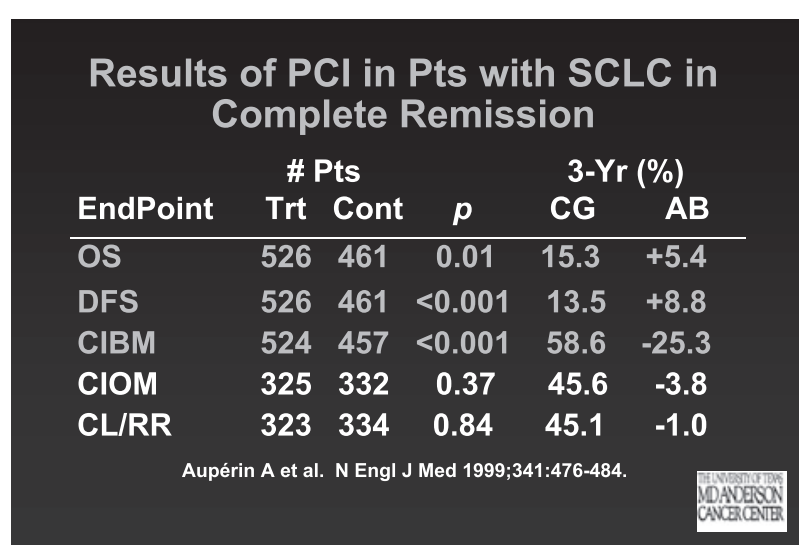

図 9.

分割 $/ 7$ 週間以上であった. ${ }^{6}$ 現在 RTOG と CALGB の共 同で TRTを BID 群 (45 Gy), CB (61.2 Gy), QD 群 (70 Gy) とした無作為比較試験が進行中である (RTOG 0538/ CALGB 30610, 図 8).

\section{予防的全脳照射}

LSCLC では中枢神経再発が約 50\% に見られると報告 されていることから, 7 予防的全脳照射 (PCI : Prophylactic cranial irradiation）による脳転移の制御も LSCLC の治療成績向上に扔ける命題の一つであった．Aupérin らは Meta-analysis の手法で局所の完全寛解 (CR) が得ら れた 987 例の LSCLC 症例において PCI が予後に与える 影響について解析した. 8 PCI が施行された 526 例の治 療成績は 3 年全生存率 $20.7 \%$ で, コントロール症例の $15.3 \%$ と比べ有意に良好であった．またPCIによって原 病死のリスク怙よび中枢神経再発のリスクが有意に低下 したと報告した（図 9）。

PCI の有用性が報告された一方で, PCI による脳の高 次機能障害についても検討された. 9-11 Komaki らが MD アンダーソンキャンサーセンターにおいて初回治療で $\mathrm{CR}$ となった LSCLC の 69 例を対象に PCI による中枢神 経障害について前向きに検討を行ったところ, $10,11 \mathrm{PCI}$ 施行前に思考や記憶など何らかの認識障害を有する症例 が約 $50 \%$ に認められた．対象となった 69 例のうち 67 例で $25 \mathrm{~Gy} / 10$ 分割の PCI が施行されたが, PCI 終了後 の認識障害は有意に増悪していた。しかしながら，その 後の経過で認識障害は PCI 施行前と同レベルに改善し, その他の機能障害の出現も認められなかった（中枢神経 に再発した症例は除く).また, PCI の線量/分割について はLe Péchoux らによる初回治療でCR が得られた 720 例を対象とした第 III 相試験で， $25 \mathrm{~Gy} / 10$ 分割（通常照 射 : $\mathrm{SD}$ ）と $36 \mathrm{~Gy} / 18$ 分割あるいは 1 日 2 回 24 分割（高 線量照射：HD）の治療成績が検討された. ${ }^{12} \mathrm{HD}$ 群では

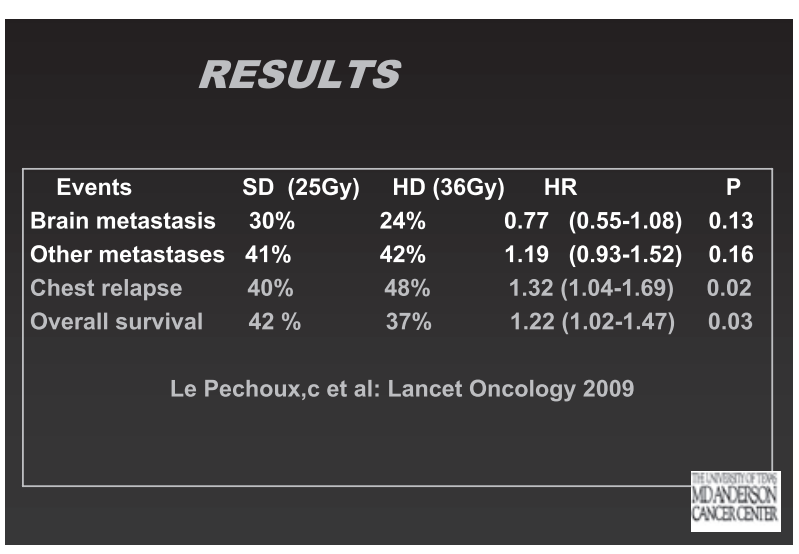

図 10.

$\mathrm{SD}$ 群と比較して有意な中枢神経再発の抑制効果は認め られず,ささらに生存期間は SD 群を下回る結果であった (図 10)。また, 脳の高次機能障害は $\mathrm{HD}$ 群で $\mathrm{SD}$ 群より も高い確率で出現した. したがって, 現時点では標準的 な PCIは $25 \mathrm{~Gy} / 10$ 分割とされている.

\section{まとめ・今後の展望}

今後, 分子標的薬剂を含めた新規薬剤の開発が期待さ れ，さらにこれらと放射線治療を組み合わせることに よって治療成績が向上する可能性があると思われる。 た，胸部放射線治療については照射するタイミングや線 量だけではなく，治療計画におけるターゲットの決定方 法も重要であると考えられる.

謝辞: 第 50 回日本肺癌学会総会・招請講演 2 の要旨とスラ イド原稿 (図)を特別寄稿として掲載させて頂くことを快諾さ れた Ritsuko Komaki 先生，ならびに学会誌「肺癌」への揭載 を快くお引き受け頂いた編集委員長の田村友秀先生に心より 感謝申し上げます〔第 50 回日本肺癌学会会長早川和重 (北里 大学医学部放射線科学) ].

\section{REFERENCES}

1. Pignon JP, Arriagada R, Ihde DC, Johnson DH, Perry $\mathrm{MC}$, Souhami RL, et al. A meta-analysis of thoracic radiotherapy for small-cell lung cancer. N Engl J Med. 1992;327: 1618-1624.

2. Warde P, Payne D. Does thoracic irradiation improve survival and local control in limited-stage small-cell carcinoma of the lung? A meta-analysis. J Clin Oncol. 1992;10: 890-895.

3. Turrisi AT 3rd, Kim K, Blum R, Sause WT, Livingston $\mathrm{RB}$, Komaki R, et al. Twice-daily compared with oncedaily thoracic radiotherapy in limited small-cell lung cancer treated concurrently with cisplatin and etoposide. $N$ Engl J Med. 1999;340:265-271. 
4. Komaki R, Swann RS, Ettinger DS, Glisson BS, Sandler $\mathrm{AB}$, Movsas B, et al. Phase I study of thoracic radiation dose escalation with concurrent chemotherapy for patients with limited small-cell lung cancer: Report of Radiation Therapy Oncology Group (RTOG) protocol 97-12. Int J Radiat Oncol Biol Phys. 2005;62:342-350.

5. Komaki R, Paulus R, Ettinger DS, Videtic GM, Bradley JD, Glisson BS, et al. A phase II study of accelerated high-dose thoracic radiation therapy (AHTRT) with concurrent chemotherapy for limited small cell lung cancer: RTOG 0239. J Clin Oncol. 2009;27(Suppl):388.

6. Choi NC, Herndon JE 2 nd, Rosenman J, Carey RW, Chung CT, Bernard S, et al. Phase I study to determine the maximum-tolerated dose of radiation in standard daily and hyperfractionated-accelerated twice-daily radiation schedules with concurrent chemotherapy for limited-stage small-cell lung cancer. J Clin Oncol. 1998;16: 3528-3536.

7. Komaki R, Cox JD, Whitson W. Risk of brain metastasis from small cell carcinoma of the lung related to length of survival and prophylactic irradiation. Cancer Treat Rep. 1981;65:811-814.

8. Aupérin A, Arriagada R, Pignon JP, Le Péchoux C, Gregor A, Stephens RJ, et al. Prophylactic cranial irra- diation for patients with small-cell lung cancer in complete remission. Prophylactic Cranial Irradiation Overview Collaborative Group. N Engl J Med. 1999;341:476-484.

9. Fonseca R, O’Neill BP, Foote RL, Grill JP, Sloan JA, Frytak S. Cerebral toxicity in patients treated for small cell carcinoma of the lung. Mayo Clin Proc. 1999;74:461465.

10. Komaki R, Meyers CA, Shin DM, Garden AS, Byrne K, Nickens JA, et al. Evaluation of cognitive function in patients with limited small cell lung cancer prior to and shortly following prophylactic cranial irradiation. Int $\mathrm{J} \mathrm{Ra}$ diat Oncol Biol Phys. 1995;33:179-182.

11. Grosshans DR, Meyers CA, Allen PK, Davenport SD, Komaki R. Neurocognitive function in patients with small cell lung cancer: effect of prophylactic cranial irradiation. Cancer. 2008;112:589-595.

12. Le Péchoux C, Dunant A, Senan S, Wolfson A, Quoix E, Faivre-Finn C, et al. Standard-dose versus higher-dose prophylactic cranial irradiation $(\mathrm{PCI})$ in patients with limited-stage small-cell lung cancer in complete remission after chemotherapy and thoracic radiotherapy (PCI 99-01, EORTC 22003-08004, RTOG 0212, and IFCT 99-01): a randomised clinical trial. Lancet Oncol. 2009;10:467-474. 